\title{
Challenges in Auditing Income Taxes in the IFRS Environment: The Czech Republic Case ${ }^{\#}$
}

\author{
Petr Vácha*
}

\section{Introduction}

Since 2005, entities which equity or debt instruments are listed on the regulated market in Europe, are required by the Czech accounting law $(\mathrm{CAL})^{1}$ to prepare their financial statement in accordance with the International Financial Reporting Standards as adopted by EU (IFRS). Since 2011, the entities that are part of the consolidated group, which prepares its consolidated financial statements in accordance with IFRS, can choose to prepare their statutory standalone financial statements in accordance with IFRS. In the Czech Republic, the scope of using IFRS is set out in Act No. 593/1991 Coll., on Accounting, as amended (Act on Accounting). The population of Czech entities listed on the European regulated markets is limited, however, the population of the Czech entities, which are subject to IFRS consolidation, (as being entities that are part of the consolidated groups which prepare its consolidated financial statements in accordance with IFRS) is significant and some of these entities may select to prepare the statutory standalone financial reporting in accordance with IFRS as allowed by the Act on Accounting.

In the Czech Republic, the choice of financial reporting framework has certain income tax consequences. The corporate income tax basis is determined in accordance with Act No. 586/1992 Coll., on Income Taxes

\# This article has been prepared under the research project Assumptions for Introduction of the IFRS as an Alternative Tax Base in a Small Open Economy: Evaluation of Its Impact on Country's Competitiveness supported by the Czech Science Foundation under the registration number P403/12/1901.

Ing. Petr Vácha - Senior Lecturer; University of Economics, Prague, Faculty of Finance and Accounting, Department of Financial Accounting and Auditing, <xvacp04@vse.cz>.

1 Czech accounting law is meant to represent a broad term for the laws and regulation related to Czech accounting. These comprise Act on Accounting and accompanying regulations, standards and other pronouncements. 
(Act on Income Taxes), as amended. The Act on Income taxes stipulates that the tax basis shall be derived as a difference between revenues and costs, after necessary adjustments set out in the Act on Income Taxes, whilst the accounting profit is used as a starting point of the determination of corporate income tax basis. For entities, which prepare their financial statements in accordance with IFRS, the Act on Income Taxes defines that such accounting profit is adjusted for the impact of IFRS, without further detailing such requirement.

The entities therefore need to be able to adjust their profit for the impact of IFRS in order to determine the starting point for setting the tax base. How the Czech entities handle such requirement varies. The range of solutions may involve the preparation of transfer bridge between IFRS and Czech accounting profit or maintaining the dual or partially dual accounting in order to maintain transparent evidence of ,what should the Czech accounting profit be" if the entity would report the statutory financial statements in accordance with CAL. The approach to practical application often depends on various factors (e.g. the size of an entity, complexity of accounting transaction, complexity of information systems, etc.). The goal of this paper is to analytically evaluate the critical points when auditing the corporate income tax payable of Czech companies reporting under IFRS regime. The importance of tests on deferred taxes and effective tax rate will be stressed.

\section{Background of auditing income taxes}

The presentation of income taxes in financial statements is discussed for a long-time by accounting research (Moonitz, 1957; Hasselback, 1976; Stickney, 1979), but it affects the auditing procedures, too. The auditor may face to the fact that firms are able to manage simultaneously accounting earnings upwards and taxable profits downwards (Desai, 2005; Whitaker, 2005), following the dichotomy (independence) between accounting and taxation systems (Manzon and Plesko, 2001; Mills et al., 2002). The purpose of audit of financial statements is to express an opinion by the auditor on whether the financial statements are prepared, in all material respects, in accordance with an applicable financial reporting framework (ISA 200). Provided that the financial statements are prepared under the fair presentation framework, the auditor engagement is to express an opinion on whether the financial statements are presented fairly, in all material respects, or give a true and fair view in accordance with the framework. The purpose of the audit is not to express separate 
opinion on income tax accounts or on entities' tax position. Nevertheless, the income tax position of the entity should be considered during the auditor's procedure related to opinion on the financial statements as a whole. Although the auditor's expression relates to financial statements as a whole, the auditor proceeds step by step over the individual accounts included in the financial statements (Ricchiute, 1992).

The auditor is obliged to plan the audit properly. One of the planning procedures is setting the auditor's materiality and, in the next step, the performance materiality on the level of individual financial statement accounts. The magnitude of balance sheet and income statement income tax accounts, together with other considerations such as volume of transactions and their complexity, determines the auditor's judgment on the volume of audit work necessary to be carried out on the income tax accounts. The magnitude of income tax accounts is not the only consideration for the volume of the auditor's procedures. The auditor should consider whether there is the inherent risk related to the income tax accounts. The inherent risk means whether the account balance is prone to material error, in absence of appropriate level of internal controls (Ricchiute, 1992). If the inherent risk of material misstatement relating to income tax accounts is higher, this will result in more auditor's procedures over these accounts in order to decrease the remaining audit risk to an acceptable level. Furthermore, an auditor should be aware of potential strategic tax behaviour of a client (Reinganum - Wilde, 1985), which may trade-off between increased utility from tax evasion and probable disutility stemming from fines if the evasion is identified. However, there is also robust evidence on honest behaviour of taxpayers, who report their tax burden truthfully regardless of the incentive to cheat (Erard - Feinstein, 1994). This mixed characteristics of clients' motivations to report tax duties honestly or untruthfully elicits concerns about appropriate procedures for testing items relating to income taxes. 


\section{Discussion of specifics of auditing income taxes under IFRS}

One of the key considerations in connection with the income tax accounts is determination of the proper audit assertions. As the income tax is usually deemed to represent the tax liability and expense, the relevant assertions are completeness of income tax expense and valuation of the income tax accounts (Müllerová - Králíček, 2014). Further, if the deferred tax asset and deferred tax income are significant, the relevant audit assertion for deferred tax accounts is existence and occurrence, respectively. For the financial reporting frameworks such as IFRS, which require significant disclosures about the income tax accounts and positions, the presentation and disclosure is another audit assertion that needs to be considered by the auditor.

During the planning audit procedures, the auditor should obtain the sufficient understanding of the income taxes that are relevant to the entity and of the processes that influence the income tax balances in the financial statements. Typically, the entities do have a process of how they identify, handle, compute, control and pay the relevant income taxes. The auditor should obtain understanding of such income tax process and document the understanding of this process. The auditor's understanding should not be confirmed only through inquiries of entity's personnel or observations; the auditor should also perform process walk-through on sample transaction and document it. During the understanding of the process, the auditor should also understand the entity's controls over the process. The auditor could further test such controls; however, that depends on the overall audit strategy adopted and on other factors. For example, a lot of income taxes involve certain sub-processes and controls that are only performed once a year which may lead to controls strategy being less relevant for these particular accounts.

Auditor's substantive testing approach to income tax accounts may take variety of forms. Analytical procedures should include comparison on year-to-year basis, actual vs. budget and development of auditor's hypothesis as for the income tax positions based on auditor's understanding of the entity's business and operations. These hypotheses are to be compared to actual figures and the results should be evaluated. Tests of reasonableness may include high-level estimations of income tax charge, income tax balance and effective tax rate. Detailed substantive procedures may include, amongst others, tie-in of financial statements 
income tax amounts to general ledger; trial balance and journal; review of roll-forward of current and deferred tax liability (receivable); tests of mathematically accuracy of underlying calculations; tie-in of significant components of income tax calculations to trial balance or another supporting evidence; review of impairment tests of deferred tax assets; vouching of tax payments; reconciliations of journal entries to tax returns; analysis of tax non-deductible or non-taxable items; re-computations; reading the reports of financial authorities and tax advisors; etc.

During the wrap-up of the audit, the auditor should perform the review of subsequent procedures on the income tax accounts, review the latest draft of tax return and seek appropriate representations of management in relation to income taxes.

As outlined above, the Act on Accounting requires listed companies and allows some other companies to prepare their standalone financial statements in accordance with IFRS. However, the tax basis remains linked to the profit before tax as determined by the CAL. There are at least two consequences of this link:

(i) the entities which are allowed to prepare their standalone financial statements in accordance with IFRS are less incentivized to do so as they still need to maintain certain Czech accounting evidence for Czech tax purposes; and

(ii) the entities that prepare their standalone financial statements in accordance with IFRS need to have separate, thorough and verifiable evidence which would enable them to determine the profit before tax in accordance with the CAL for the purpose of computation of the corporate income tax.

There could be various ways how to ensure that this requirement is maintained. They are similar to general methods of financial statements conversion (Procházka, 2011) adjusted for the purpose of income tax calculation. The following are examples of such approaches:

1. The entity keeps the evidence of the accounting and reporting areas, which are different in IFRS and CAL and prepares the manual bridge between the profit before tax in accordance with IFRS (IFRS profit before tax) and profit before tax in accordance with CAL (Czech profit before tax). Through this bridge and adjustments applied, the entity determines the profit before tax for tax purposes.

Preparation of the bridge between IFRS and Czech profits before tax looks as a simple solution for the tax requirement. However, it triggers 
number of important "what can go wrongs" (ISA 315) which the auditor needs to take into account during the planning and performance of the audit procedures:

a. The transfer bridge containing adjustments between profits may be suitable solution only for smaller and less-complex entities with relatively simple business and may not be suitable for larger businesses with transactions that are more complex and possessing many differences between IFRS and CAL.

b. The completeness of the list of adjustments is the audit risk. Unless full evidence is maintained in relation to reporting in accordance with IFRS and CAL, the entity may forget about the adjustments between these two reporting frameworks, due to either omission to capture those initially or failure to identify those when new business transactions arise or new development in any of these two reporting frameworks. Auditor's understanding of the adjustments with respect to the understanding of the business, transactions and both reporting frameworks should be part of the planning and interim stage of the audit and it should be updated during the year-end audit phase. Unless the entity has solid controls over the completeness of adjustments and good methodology personnel, the entity's approach to determine the basis for tax purpose through the selected adjustments applied on IFRS profit before tax may represent higher audit risk. It is then particularly demanding on the auditor's high level of professional scepticism and thorough understanding of the current year changes in business and financial reporting.

c. Valuation of such adjustments is another audit risk. The profit before tax adjustment may be properly identified but may not be properly calculated. Apart from planning and process/control procedures, the auditor typically applies the detailed substantive procedures including the analytical procedures, reasonableness tests and re-computations in response to the valuation risk.

d. In situations where the profits are reconciled through adjustments, the auditor usually considers the reliability of the supporting data as an increased risk. This is because often the data supporting the adjustments are not automatically 
transferred from the information system but are often extracted manually or the human factor plays extended role in capturing and entering the source data into the adjustment models. Where the adjustments are kept off the integral information systems (e.g. when such adjustments are kept in table worksheets), the auditor should consider increased testing of electronic audit evidence (ISA 500).

e. Where the entity derives the Czech profit before tax through applying adjustments to IFRS profit before tax, appropriate attention needs to be given by auditor to procedures on opening balances. When the adjustments are not part of the entity's information system and therefore do not fall under the automated system of closing and opening accounts with transfer of prior year profit to retained earnings, there could be higher risk. The higher risk may emerge because the entity incorrectly roll-forwards the adjustment from prior to current year and consequently incorrectly calculates the current year effect on profit before tax for tax purposes and income tax itself.

2. The entity keeps sufficient evidence, which can independently allow the entity to determine the IFRS profit before tax and Czech profit before tax. This is typically achieved through setting up the information system, which supports the accounting, and financial reporting in accordance with both reporting frameworks. Nevertheless, although this approach is more thorough than transfer bridge mentioned above, it also represents the challenges for the auditor:

a. In many of such systems, the entities do not apply full dual accounting where all the journal entries would be separately entered into each of the reporting frameworks. Rather it is common that part of the accounting that is identical for both frameworks is entered into the information system just once and the system solution allows these journal entries to be replicated to second framework. In such situations it is also often the case that one of the reporting frameworks is considered as primary one into which the common entries are initially entered. It is the auditor's task to sufficiently understand the set-up and related risks, as there is the risk that the entities devote more attention to primary framework and 
less attention to secondary framework. So if the CAL is set as primary framework in the system, there may be less risk with reliability of profit for tax purposes but more risk whether appropriate attention to given by entity's personnel to IFRS reporting and vice versa.

b. Unless the system is fully dual, similarly to $1 \mathrm{~b}$ above the completeness of accounting entries into second framework may represent the increased audit risk that the auditor should address.

c. Important consideration for auditor's judgment about the audit risk is how the methodology/accounting personnel is organized in the entity with respect to both frameworks. The methodology/accounting department may be organized based on framework, processes or financial statement components (e.g. fixed assets). In the latter example, the question typically arises how well trained the methodology/accounting personnel is in both frameworks and whether appropriate attention is given to both frameworks by those specialists.

d. The auditor shall also consider the information system implications on the audit. The entities, which keep the separate evidence to allow them to determine the profit before tax in both frameworks, typically do so within the integrated information system. This will lead to higher portion of the audit to be devoted to procedures on IT general controls and application controls and thorough understanding of the entity's IT environment.

Notwithstanding which solution is adopted to determine the profit before tax for tax purpose in the environment of IFRS reporting, one of the most difficult challenges which the entity and the auditor needs to address within the requirement to "not take account of IFRS influence for the determination of the tax basis" is to assess the meaning of "influence of IFRS" on each individual entity. To understand these challenges, the following could be mentioned as an example:

- The Czech accounting has been historically rather rule-based although recently the principle of true and fair view has been established. It is not yet clear in which cases could this true and fair principle be applied in still prevailing rule-based accounting system. 
- The IFRS influence led to some recent changes in the CAL. Amongst others, the method of correction of errors, component approach to fixed assets could be named.

- Despite Czech accounting being primarily rule-driven, in many financial statements areas the rules are not detailed enough to provide sufficient guidance how to account for transactions. One of these areas where rules do not provide sufficient guidance for entities in the Czech accounting is revenue as described by Vácha (2013).

- The Czech accounting lacks integrated conceptual framework that would provide some guidance in absence of detailed rules.

As a result, for the entities reporting in accordance with IFRS it may be particularly difficult to determine which accounting practices should be applied differently for Czech accounting purposes from those applied in IFRS and therefore be considered as an area of adjustment/influence of IFRS. The entities which prepare their financial statements in accordance with IFRS often have to consider "what they would do" if they prepared the financial statements in accordance with CAL without preparing IFRS financial statements as for the number of areas the detailed guidance exists in IFRS and does not exist in Czech accounting. This is one of the major challenges when determining the profit before tax for tax base purposes and subsequently the corporate income tax. It often includes very judgmental decisions by the entity, which would not be necessary if instead of relying on elimination of "IFRS influence" from accounts, the detailed tax rules would exist for the purpose of the corporate income tax calculation.

From auditor's perspective, testing the entity's judgment on what constitutes "IFRS influence" represents one of the most demanding areas on auditor's understanding of entity's business and knowledge of both financial frameworks. The auditor is further challenged by the fact that the Czech accounting is still in some areas linked with tax law. Therefore, the auditor may use, apart from auditor's own procedures on the income taxes, the assistance in of auditor's expert - tax specialist - in identification of risks and carrying procedure on income tax accounts and determination of corporate income tax base to decrease the audit risk to acceptable level (ISA 620).

Apart from the determination of the tax base, the auditor should address also the specifics of deferred tax in the IFRS environment. As 
compared to the entities that prepare the financial reporting in accordance with CAL, further taxable or allowable temporary differences arise because of difference between CAL and IFRS. The inherent risk connected with the deferred tax is usually lower when only few areas of difference between CAL and IFRS exist. However, in case of partially dual or dual evidence because of significant amount of adjustments, the sufficient tests on valuation of deferred tax in connection with the difference between IFRS and tax balance should be performed if the deferred tax balance is significant.

In connection with the specifics relating corporate income tax and deferred income tax, the reasonableness test of effective tax rate is, amongst others, one of the very useful audit tests. As the possibility of long-run corporate tax avoidance has been identified by Dyreng et al. (2008), checking the simultaneous development of current and deferred tax may serve as indication of hidden tax management. Effective tax rate is defined by International Accounting Standard 12 as income tax expense or benefit for accounting purposes divided by accounting profit. Especially with respect to standalone financial statements, the effective tax rate may be indicative of overall reasonableness of income tax charge or its misstatement on the other side. The effective tax rate however could not identify any reclassification misstatements between current and deferred tax. The benefit of the reasonableness test on effective tax rate is also directly dependent on the auditor's understanding of the entity's tax position, key tax risks and one-off impacts such as investment tax incentives. Finally, tests based on deferred taxes may be valuable for detecting earnings management of a company and thus identifying other sources of misrepresentations in financial statements (Phillips et al., 2003).

\section{Conclusion}

The area of income taxes is one of the most judgmental areas during the audit of financial statements. It is demanding on good planning of the audit procedures, proper and thorough identification of the key tax risks and mix of process, control and substantive procedures. Auditing the area of income taxes is even more challenging for auditors of Czech entities that prepare their financial statements in accordance with IFRS. Apart from the typical auditing issues in this area, further complexity is brought by the requirement that these entities use for the determination of the tax basis the accounting profit before tax without taking into account the influence of IFRS. 
The CAL does not specify further this requirement and it causes variety of ambiguities in practice of those Czech entities reporting in accordance with IFRS. The process of determining what should be understood as influence of IFRS may be very complex and involves decisions on entity level in terms of system and process solution and also on transaction level in terms of what IFRS treatment could be acceptable for Czech accounting. In absence of detailed rules for recording transactions in some areas of Czech accounting, these decisions may be very arbitrary and will inevitable involve a significant judgments made by the entity. Consequently, the auditors would need to address the risks that these judgments would result in material misstatement of the income tax in the financial statements. The auditors also need to understand the whole process of conversion of IFRS profit before tax to Czech profit before tax. There are important audit assertions to be considered and tested if relevant - valuation, completeness, occurrence and presentationdisclosure amongst the key ones.

The level of ambiguity in interpretation of the requirement for determination of tax base in IFRS environment does not help either entities or auditors. The question arises why the entities, which prepare the financial reporting under IFRS, need to convert their profit before tax first to different accounting framework (Czech accounting) only for the purpose of the determination of appropriate tax base. This is often hard to achieve without maintaining at least partially dual accounting, which is the state that hardly was intended by requiring these entities to report under IFRS. In addition, some of the areas, which are differently treated in CAL as compared to IFRS, have their further specific rules in Czech tax regime. Therefore, further steps should be taken to implement sufficient rules into the Czech tax laws that will, if needed, provide detailed guidance for areas in which the tax regulator does not accept the IFRS treatment. The enhanced tax rules should be directed in the way that the entities, which report in accordance with IFRS, can have only one financial reporting system and single evidence for tax purposes.

\section{References}

Desai, M. A. (2005): The Degradation of Reported Corporate Profits. Journal of Economic Perspectives, vol. 19, no. 4, pp. 171-92.

Dyreng, S. D. - Hanlon, M. - Maydew, E. L. (2008): Long-Run Corporate Tax Avoidance. The Accounting Review, vol. 83, no. 1, pp. 61-82. 
Vácha, P.: Challenges in Auditing Income Taxes in the IFRS Environment: The Czech Republic Case.

Erard, B. - Feinstein, J. S. (1994): Honesty and Evasion in the Tax Compliance. The RAND Journal of Economics, vol. 25, no. 1, pp. 1-19.

Hasselback, J. R. (1976): An Empirical Examination of Annual Report Presentation of the Corporate Income Tax Expense. The Accounting Review, vol. 51, no. 2, pp. 269-276.

Manzon, G. B. - Plesko, G. A. (2001): The Relation between Financial and Tax Reporting Measures of Income. Tax Law Review, vol. 55, no. 2, pp. 175-214.

Mejzlík, L. (2006): Možnosti a rizika technologického řě̌ení převodu českých účetních závěrek do IFRS. Český finanční a účetní časopis, vol. 1, no. 1, pp. 84-98.

Mills, L. F. - Newberry, K. J. - Trautman, W. B. (2002): Trends in BookTax Income and Balance Sheet Differences. Tax Notes, vol. 96, no. 8, pp. 1109-1124.

Moonitz, M. (1957): Income Taxes in Financial Statements. The Accounting Review, vol. 32, no. 2, pp. 175-183.

Müllerová, L. - Králíček, V. (2014): Auditing. Praha: Nakladatelství Oeconomica, 2014.

Phillips, J. - Pincus, M. - Olhoft Rego, S. (2003): Earnings Management: New Evidence Based on Deferred Tax Expense. The Accounting Review, vol. 78, no. 2, pp. 491-521.

Procházka, D. (2011): Konverze české účetní závěrky na účetni závěrku dle IFRS + aplikační CD. Praha: Nakladatelství Oeconomica, 2011.

Reinganum, J.r F. - Wilde, L. L. (1985): Income Tax Compliance in a Principal-Agent Framework. Journal of Public Economics, vol. 26, no. 1, pp. 1-18.

Ricchiute, D. N. (1992): Audit. South-Western Publishing Co., USA, 1992.

Stickney, C. P. (1979): Current Issues in the Measurement and Disclosure of Corporate Income Taxes. The Accounting Review, vol. 54, no. 2, pp. 421-433.

Vácha P. (2013): The impact of lack of accounting guidance in the area of revenue recognition from the perspective of Czech accounting. The 14th Annual Doctoral Conference of Faculty of Finance and Accounting, Prague, 2013.

Whitaker, C. (2005): Bridging the Book-Tax Accounting Gap. The Yale Law Journal, vol. 115, no. 3, pp. 680-726. 
The International Financial Reporting Group of Ernst \& Young (2012): International GAAP 2012: Generally accepted accounting practice under International Financial Reporting Standards. United Kingdom, John Wiley \& Sons Ltd., 2012.

International Auditing Standard (ISA) 200 - Overall objectives of the independent auditor and the conduct of an audit in accordance with International Standards on Auditing

International Auditing Standard (ISA) 315 - Identifying and Assessing the Risks of Material Misstatement through understanding the Entity and its Environment

International Accounting Standard (ISA) 500 - Audit evidence

International Accounting Standard (ISA) 620 - Using the work of an auditor's expert

International Accounting Standard (IAS) 12 - Income Taxes

Act No. 563/1991 Coll., on Accounting, as amended

Act No. 586/1992 Coll., on Income Taxes, as amended 


\title{
Challenges in Auditing Income Taxes in the IFRS Environment: The Czech Republic Case
}

\begin{abstract}
This article looks at the complex and judgmental area of auditing income taxes in the environment of financial reporting in accordance with International Financial Reporting Standards as adopted by EU (IFRS) in the Czech Republic. In the first section, the main regulations that apply to entities preparing IFRS financial statements and their influence on income tax base are outlined. The second section summarizes the key steps in addressing risk of income tax misstatements when auditing financial statements. The third section discusses the specifics of auditing income taxes in the Czech environment and the alternative approaches the entities may adopt with respect to determining the profit before tax for tax purposes and challenges it represents for the auditor. This section also briefly notes some other aspects of income tax auditing such as challenges connected with the deferred tax, effective tax rate testing or using the auditor's expert for the audit procedures. The conclusion suggests more detailed rules to be provided by the tax legislation with respect to ambiguities which current situation brings to both entities and their auditors.
\end{abstract}

Key words: Auditing; Income taxes; IFRS.

JEL classification: M42 